\title{
Local Endoscopic Treatment of Locally Advanced Pancreatic Cancer
}

\author{
Jun Seong Hwang, Sung Woo Ko, Hoonsub So, Tae Jun Song \\ Division of Gastroenterology, Department of Internal Medicine, Asan Medical Center, University of Ulsan College of Medicine, Seoul, Korea
}

Pancreatic adenocarcinoma is one of the cancers with the poorest prognosis, and its incidence has gradually increased to become the 9th most common cancer in Korea in 2016. Surgical resection is the only treatment option to improve the cure and longterm survival rate. Unfortunately, only $10 \%$ to $20 \%$ of all pancreatic cancer patients present with resectable disease, because of common symptoms are rarely noticeable in its early stages and disease progress very quickly. Unresectable pancreatic cancer can be divided into locally advanced pancreatic cancer (LAPC) and metastatic disease. Pancreatic cancer with distant metastasis accounts for about $40-60 \%$ of the total pancreatic cancer and systemic chemotherapy is considered as standard treatment. LAPC is observed in $30-40 \%$, defined as the tumor surrounding major blood vessels (especially, celiac artery and superior mesenteric artery) more than $180^{\circ}$ without distant metastasis which cannot be completely removed by surgery. Standard treatment for LAPC has not yet been established, and chemotherapy and radiotherapy have mainly been used, but in most cases, response to these therapeutic options has been limited. As imaging techniques, endoscopic devices and procedures have recently been developed and the role of local endoscopic therapies for LAPC has expanded. This article provides an overview of local endoscopic treatment for LAPC such as injection therapy, radiofrequency ablation (RFA), irreversible electroporation (IRE), radiotherapy and drug-delivery stent insertion.

Korean J Pancreas Biliary Tract 2020;25(2):83-92

Keywords: Locally advanced pancreatic cancer (LAPC), Pancreatic cancer, Endoscopic treatment

\author{
Received Oct. 30, 2019 \\ Revised Dec. 10, 2019 \\ Accepted Dec. 13, 2019
}

Corresponding author : Tae Jun Song

Division of Gastroenterology, Department of Internal Medicine, Asan Medical Center, University of Ulsan College of Medicine, 88 Olympic-ro 43-gil, Songpagu, Seoul 05505, Korea

Tel: +82-2-3010-3914

Fax: +82-2-476-0824

E-mail: drsong@amc.seoul.kr

ORCID: https://orcid.org/0000-0002-6156-8746

\section{서 론}

2018 년 보건복지부와 중앙암등록본부에서 발표한 국가암등록통계자료에 따르면 2016년 췌장암은 전체 암종 중 발생등록 분율 $2.9 \%$ 로 9 위를 차지하였고, 최근 10 년간 발생률은 지속적으로 증가 추세를 보이고 있다. ${ }^{1}$ 진단 및
치료법들의 발달로 위암(33.2\%), 대장암(21.1\%), 간암(23.9\%) 등의 다른 소화기계 암들의 5 년 생존율이 크게 향상되었음에도 불구하고 췌장암의 5 년 생존율은 $11.4 \%$ 로 극히 불량한 예후를 보였다. 수술적 절제만이 완치 및 장기 생존율을 높이는 유일한 방법이나, ${ }^{2}$ 초기부터 진행된 시기까지 특징적인 증상이 없고 종양의 성장 속도가 빠르며, 주위 조직과 림프절로 침윤 및 
전이가 쉽게 일어나 진단 당시 수술이 가능한 경우는 전체 췌장암 환자 중 10-20\%에 불과하다. ${ }^{3,4}$ 절제가 불가능한 췌장암은 이미 다른 장기로 원격전이가 동반된 경우와 국소진행성 췌장암으로 나눌 수 있다. 원격전이가 동반된 췌장암은 전체 췌장암의 $40-60 \%$ 정도를 차지하며, 항암화학 치료 및 방사선 치료가 표준 치료이다. ${ }^{5,6}$ 국소진행성 췌장암은 $30-40 \%$ 에서 관찰되며, 원격전이는 없으나 주위 주요 혈관(특히, 복강 동맥[celiac artery]과 상장간동맥[superior mesenteric artery])을 $180^{\circ}$ 이상 침범하여 수술로 완전히 제거할 수 없는 병기에 해당한다. ${ }^{7}$ 국소 진행성 췌장암에 대한 표준 치료는 아직 정립되지 않았으며, 항암화학 치료 및 방사선 치료가 주로 시행되었으나, 대부분의 경우에서 항암제에 대한 치료 반응이 제한적이었다. ${ }^{8-10}$ 최근 들어 내시경 장비 및 술기가 발달함에 따라 내시경적 국소 치료의 적용 범위가 확대되고 있으며, 특히 국소진행성 췌장암에 대한 내시경적 국소 치료가 종양의 크기 감소 및 통증 등의 증상 완화에 효과적이었다는 연구 결과들이 보고되고 있다. ${ }^{11,12}$ 이에 본고에서는 국소진행성 췌장암에 대한 내시경적 국소 치료, 특히 내시경 초음파 (endoscopic ultrasound, EUS) 유도하 항암제 주입술 및 바이러스 벡터 주입술(virotherapy), 고주파 열 치료(radiofrequency ablation, RFA), 비가역적 전기천공술(irreversible electroporation, IRE), 정위적 방사선 치료를 위한 표식자 삽입술(fiducial marker insertion) 및 약물 방출 스텐트 삽입술 등의 내시경적 국소 치료의 종류, 효과 및 합병증 등에 대하여 고찰해 보고자 한다(Table 1).

Table 1. Local endoscopic treatment for pancreatic cancer

1. Injection therapy
1) Chemotherapeutic agents
2) Viral and immunologic vectors
2. Ablation therapy
1) RFA
2) IRE
3. Radiotherapy
1) Fiducial marker insertion
2) Brachytherapy
4. Drug delivery stents

RFA, radiofrequency ablation; IRE, irreversible electroporation.

\section{본 론}

\section{EUS 유도하 세침 주입술}

현재 EUS 유도하 세침 주입술(EUS-guided fine-needle injection, EUS-FNI)이 가장 활발하게 적용되는 질환은 췌장 낭종이며, 고형 종양, 특히 췌장암에 대한 EUS-FNI는 임상에서 제한적으로 적용되고 있다. 그러나 췌장암은 혈관이 적고, 결합조직 증식반응(desmoplasia)이 심한 종양미세환경적 특징 때문에 종양으로의 약물 전달률이 낮아 항암화학 치료에 대한 효과가 다른 암종에 비해 떨어진다. ${ }^{13} \mathrm{EUS}-\mathrm{FNI}$ 를 통한 종양에 대한 항암물질의 국소 주입은 항암화학 치료의 전신 부작용을 줄이는 동시에 종양으로의 약물 전달률을 높일 수 있는 방안으로 기대되었으며, 몇 가지 주입 가능한 제형의 약제들에 대한 실험 결과들이 보고되었지만 현재까지 생존 기간 연장 등의 명확한 효과를 보인 연구 결과는 없는 실정이다.

\section{1) Chemotherapeutic agents}

\section{(1) Gemcitabine}

Levy 등 ${ }^{14}$ 은 절제 불가능한 췌장암 환자 36 명에서 EUS를 이용하여 gemcitabine을 췌장암에 주입하였다. 4-14일에 걸쳐 $38 \mathrm{mg} / \mathrm{mL}$ 의 gemcitabine을 EUS-FNI를 통해 투여한 결과, 환자군의 6 개월과 1 년 생존율은 각각 $76 \%$ 와 $46 \%$ 였으며, 세 명의 환자에서 절제 가능한 병변으로 downstage 되었고, 세 명 모두 R0 절제를 받았다.

\section{(2) OncoGel}

2007년 Matthes 등 ${ }^{15}$ 은 종양 내 주입이 가능한 Paclitaxel 제형(OncoGel; MacroMed Inc., Salt Lake City, UT, USA)을 EUS 유도하에 돼지 췌장에 주입한 실험 결과를 보고하였다. 8 마리 돼지의 췌장에 EUS유도하에 1-4 mL의 OncoGel을 주입하였으며, 모든 경우에서 췌장염이나 복강 내 감염 등의 합병증 없이 실험을 완료하였다. 약물 주입 14 일 후에도 췌장 조직 내에 치료 범위의 paclitaxel 농도가 유지됨이 확인되었으나, 주입 부위로부터 30-50 mm 이상의 거리에서는 적절한 약물 농도가 유지되지 못하는 한계를 보였다. 또한 EUS-FNI를 이용한 항암제의 주입은 고밀도 섬유화를 동반한 췌장암의 특성 상 정확한 바늘 천자와 종양 내 적절한 양의 주사액 주입이 어렵다는 문제점이 있었다. 
이상의 결과들을 종합하면 EUS-FNI를 통한 종양 내 항암물질 주입술은 종양 세포 사멸을 효과적으로 유도할 수 있을 것으로 기대되었으나, 췌장암 환자의 생존율을 현저하게 개선하는 등의 효과는 입증하지 못하였다. 따라서 향후 치료적 적용을 위해서는 추가적인 연구가 필요할 것으로 사료된다.

\section{2) Viral and biologic vectors}

특정 유전자 조작 바이러스의 종양에 대한 선택성 및 종양 세포에서 세포 용해 유발 능력에 초점을 두고 절제 불가능한 췌장암에서 바이러스를 이용한 항암 요법이 연구되었다. 이러한 바이러스는 악성 세포의 유전자만을 표적으로 하며, 정상 세포 내에서는 파괴하지 않도록 유전적으로 조작된다. ${ }^{16}$ 절제 불가능한 췌장암에서 바이러스 벡터를 이용한 항암 요법은 정맥 내 주입법, 수술을 통한 주입법, computed tomography (CT)를 이용한 주입법 등의 방법이 고안되었으나 EUS를 이용한 주입법 외에는 대부분 상당한 부작용 및 이환율을 갖는 것으로 밝혀졌고 몇몇 동물모델 및 임상시험 결과가 보고되었다. ${ }^{17}$

\section{(1) Adenovirus}

ONYX-015는 정상 세포에서 종양 억제 유전자인 p53에 결합하여 세포주기의 진행 및 바이러스 복제를 유발하는 $\mathrm{E} 1 \mathrm{~B}$ 유전자가 결여되도록 설계된 adenovirus이다. E1B가 결여된 바이러스는 일반적으로 정상 세포에서는 복제되지 않는다. 췌장암의 경우 종양 세포의 50-75\%에서 p53이 결여되어 있어 $\mathrm{E} 1 \mathrm{~B}$ 가 결여된 바이러스가 복제될 수 있으며, 복제된 바이러스는 근처의 종양 세포로 퍼지게 된다. Hecht 등 ${ }^{17}$ 은 절제 불가능한 췌장암 환자 21명에게 EUS 유도하에 ONYX-015를 주입하는 임상시험 I/II를 시행하였다. EUS-FNI 프로토콜은 주사당 $1 \mathrm{~mL}$ 의 바이러스로 구성되었으며, 종양 크기에 따라 세션당 최대 10 회의 주사로 8 주 동안 총 8 회의 세션이 이루어졌다. 마지막 4 번의 세션에서는 정맥 내 gemcitabine $\left(1,000 \mathrm{mg} / \mathrm{m}^{2}\right)$ 이 함께 투여되었다. 치료 시작 8 주 후 반응을 평가한 결과, 단지 2 명의 환자에서만 부분 치료 반응을 보였으며, 11 명의 환자에서 진행성 병변을 보이거나 치료 독성으로 인하여 연구를 중단해야 했다.

\section{(2) Herpes virus}

Herpes virus는 강력한 T세포 매개 종양 반응성을 가지며, 암에 대한 면역 반응을 간접적으로 유발하여 신체의 방어
세포에 의한 종양의 국소적 사멸 및 파괴를 유발할 수 있다. 현재까지 여러 종류의 herpes virus를 이용한 동물실험이 시행되었다. ${ }^{18,19}$ 또한 EUS를 통해 주입 가능한 herpes virus는 OncoVex GM-CSF가 대표적이다. OncoVex GM-CSF를 이용한 연구는 이 바이러스가 인간 GM-CSF를 발현하여 종양 근처로 수지상 $\mathrm{T}$ 세포의 동원 및 활성화를 강화하고, 종양 파괴를 촉진할 것이라는 가설로부터 시작되었다. ${ }^{20,21}$ 췌장암 환자에서 OncoVex GM-CSF 바이러스를 이용한 EUS-FNI 임상시험 결과는 아직 발표되지 않았다. ${ }^{21}$

\section{(3) Other viruses}

상기 언급된 바이러스 외에 poxvirus ${ }^{22}$, parvovirus ${ }^{23}$, measles virus $^{24}$ 등을 이용한 in vitro 및 in vivo 연구가 진행되었으나 아직 인체에서 내시경적 초음파를 이용한 임상시험은 시행되지 않았다.

\section{(4) Immunotherapy}

바이러스 요법 이외에도 췌장암 환자에서 국소 면역 반응을 향상시키기 위하여 EUS를 이용한 면역 치료제들의 종양 내 투여법에 대한 연구들이 시행되었다. 첫 번째는 세포 이식술(cytoimplant)이다. Chang 등 $^{25}$ 은 8 명의 진행성 췌장암 환자에게 EUS 유도하에 동종이형 혼합 림프구를 주입한 1상 임상시험 결과를 보고하였다. 세포 이식물은 건강한 공여자 및 환자의 말초 혈액 내 단핵 세포를 공동 배양하여 생성하였다. 세포 이식으로 사이토카인의 방출 및 면역 세포의 활성화가 일어날 것으로 기대하였으나, 단지 2 명의 환자에서만이 부분 치료 반응을 보였으며, 중앙 생존기간은 13.2 개월이었다.

두 번째로 EUS 유도하 수지상 세포(dendritic cells) 주입술이 있다. 수지상 세포 주입술은 2007년 Nonogaki 등데 에 의해 처음 보고되었다. 이후 몇 차례의 소규모 연구가 시행되었으나, 모두 생존기간 연장 등의 의미 있는 결과를 보여주지는 못하였다.

세 번째는 EUS 유도하 TNFerade 주입술이다. TNFerade는 방사선 유도성 프로모터(Egr-1)에 의해 조절되는 인간 종양괴사인자-알파(TNF-alpha) 유전자를 보유하는 복제-결핍 아데노 바이러스 벡터이다. Hecht 등 $^{27}$ 은 50 명의 췌장암 환자에서 TNFerade 주입법과 항암화학 방사선 치료를 병행한 I/II기 임상 연구 결과를 발표하였다. TNFerade는 EUS-FNI 또는 경피적으로 국소 진행성 췌장 암종에 주입되었으며, 환자들은 5.5 주 동안 매일 $50.4 \mathrm{~Gy}$ 의 방사선 치료를 받고 정맥을 통해 $5-\mathrm{FU}\left(200 \mathrm{mg} / \mathrm{m}^{2}\right)$ 를 투여 받았다. 각각 1명의 완전 치료 반응, 
3 명의 부분 치료 반응, 12 명의 안정된 질병 상태를 보였다. 그리고 7명의 환자가 수술적 절제를 받을 수 있었고, 이 중 6 명의 환자에서 R0 절제가 가능하였다. 이 중 3 명은 24 개월 이상 생존하는 결과를 보였다.

\section{2. 국소 종양 제거술}

열이나 레이저 등을 이용한 종양의 국소 절제는 여러 고형암 치료에 많이 이용되고 있으며, 최근 들어 내시경 술기, 장비 및 영상 기법 등의 발달로 수술 불가능한 췌장암에 대한 국소 치료에 대한 관심도 늘어나고 있다. 췌장암의 국소 치료를 통해 종양의 크기 감소 및 병기의 하향 조정 등이 가능할 것이라는 기대와 함께, 적용 가능한 국소 치료의 방법들이 다양하게 개발되고 있다. 여러 국소 치료법들 중 RFA와 IRE는 각각 열 절제 기법(thermal ablative techniques)과 비열 절제 기법 (non-thermal ablative techniques)의 대표적인 방법들로, 여러 연구들을 통해 효용성과 안전성이 제시된 바 있다.

\section{1) EUS 유도하 RFA}

EUS 유도하 RFA (EUS-guided radiofrequency ablation, EUS-RFA)는 $500 \mathrm{kHz}$ 내외의 고주파 교류가 조직에 가해지면 세포 내 이온의 동요(agitation)가 일어나게 되고, 이때 발생하는 열에 의해 세포 사멸 및 조직의 응고 괴사가 일어나는 원리를 이용한 국소 치료법이다. ${ }^{28}$ 또한 RFA는 열 파괴 효과와는 별도로 종양 특이 $\mathrm{T}$ 림프구의 활성화와 열 충격 단백질 70 (heat shock protein 70)의 발현을 유도함으로써 2차 항암 면역 반응의 역할을 하는 것으로도 보인다. ${ }^{29,30} \mathrm{RFA}$ 는 간, 폐 및 신장 등의 고형암의 치료에는 널리 이용되어 왔지만 열 손상으로 인한 췌장염과 췌관 및 췌장 주위 구조물의 손상에 대한 위험성, 기술적 어려움 등으로 췌장 종양의 치료에서는 잘 사용되지 않았다. ${ }^{31}$ 그러나 최근에는 절제 불가능한 췌장암 환자에서 복강경을 이용하거나 경피적 방법으로 췌장 종양에 대하여 $\mathrm{RFA}$ 를 시행하였고, ${ }^{32}$ 또한 여러 동물실험을 통해 췌장에 대한 EUS-RFA 역시 안전하게 적용 가능하다는 연구 결과들이 보고되었다. ${ }^{11,33}$ 동물모델을 이용한 췌장에 대한 EUS-RFA는 1999 년 Goldberg 등 ${ }^{34}$ 에 의해 처음 보고되었다. EUS 유도하에 $19 \mathrm{G}$ 바늘 전극을 돼지 췌장 미부로 진입시킨 후 전극의 온도를 $90 \pm 2{ }^{\circ} \mathrm{C}$ 로 6 분간 유지한 결과 직경 $10 \mathrm{~mm}$ 내외의 응고 괴사가 발생하였다. 그러나 초기의 동물실험 모델들은 췌장이 후복막에 위치하고 담관이 인접해 있으며 주위에 주요 혈관이

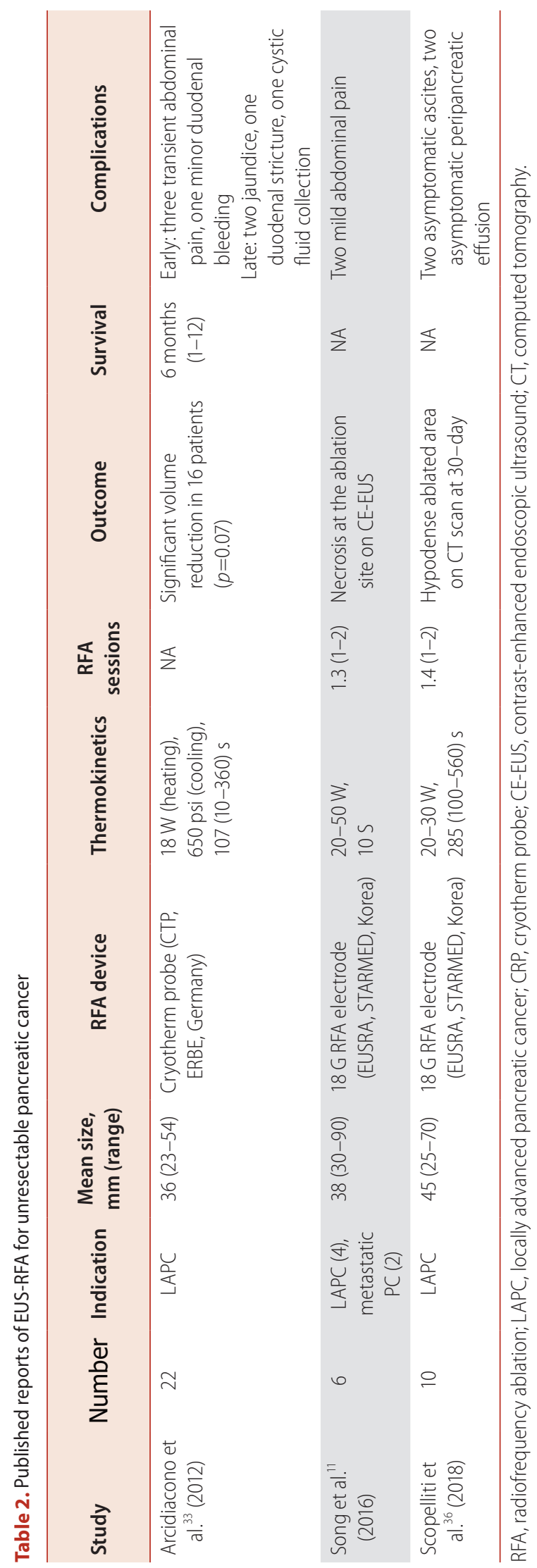


분포하고 있어 기술적으로 쉽지 않고, 최적의 열 절제와 합병증을 최소화할 수 있는 이상적인 온도의 설정 등에 어려움이 있었다. Kim 등 ${ }^{35}$ 은 성인 미니 돼지 10 마리를 대상으로 한 연구에서 췌장 몸통과 꼬리 부위에 대한 EUS-RFA의 안전성, 타당성 및 효능 등을 입증하였다. 이 연구에서는 전극 내부에 저온 식염수를 이용한 냉각 시스템을 갖춘 $18 \mathrm{G}$ 바늘 전극을 이용하여 $50 \mathrm{~W}$ 의 전력으로 5 분간 돼지의 정상 췌장에 대하여 EUS-RFA를 시행하였다. RFA 시행 후 평균 직경 $23 \mathrm{~mm}$ 정도의 응고 괴사가 발생함을 확인하였다. 부검 결과, RFA 시행 부위 이외의 췌장 조직 괴사나 췌관 및 혈관 손상 등의 합병증은 관찰되지 않았다. 따라서 췌장에 대한 EUS-RFA가 안전하게 실현 가능하고 효과적인 치료 방법이 될 가능성이 있음을 확인하였다. 이후 절제 불가능한 췌장암에 대한 EUS-RFA의 기술적 적용 가능성과 안전성 그리고 치료 성적 등에 대한 연구 결과들이 보고되기 시작하였다(Table 2). 2012년 Arcidiacono 등 ${ }^{33}$ 은 국소 진행성 췌장암 환자 22명에 대하여 전극 내부가 이산화탄소로 냉각되는 양극성(bipolar) RFA 전극(cryotherm probe, CTP, ERBE, Germany)을 이용하여 cryothermal ablation을 시행하였다. 가열 시에는 $18 \mathrm{~W}$ 의 전력을 사용하였으며, 냉각 시에는 $650 \mathrm{psi}$ 의 고정 압력을 사용하였고, 에너지 전달 평균 시간은 107초(10-360초)였다. 16 명의 환자에서 의미 있는 종양 용적의 감소를 보였으며, 조기 합병증으로 일시적인 복통(3명)과 경미한 십이지장 출혈(1명) 그리고 후기 합병증으로 황달(2명), 십이지장 협착(1명) 및 췌장 주위 체액 저류(1명)가 있었다. 2016년 Song 등 ${ }^{11}$ 은 국소 진행성 췌장암 환자 6 명을 대상으로 $18 \mathrm{G}$ 바늘 전극을 이용한 EUS-RFA의 연구 결과를 발표하였다. 췌장 두부암이 4명, 체부암이 2명이었으며, 종양 크기의 중간값은 $3.8 \mathrm{~cm}(3-9$ $\mathrm{cm}$ )였다. 종양의 크기에 따라 20-50 W의 에너지를 이용하여 한 부위에서 10 초간 RFA를 시행하고 이후 위치를 변경하여 전체 종양을 소작할 때까지 반복하였다. 평균 RFA 세션은 1.3 회였다. 시술 후 조영증강 EUS를 시행하였을 때 RFA를 시행한 부위는 조영증강이 되지 않으나 주위 조직에는 혈류가 증가된 소견이 관찰되었다. 합병증으로는 2 명의 환자에서 경미한 복통만이 있었다. 또한 2018년 Scopelliti 등 ${ }^{36}$ 은 전신 항암화학치료 중인 절제 불가능한 췌장암 환자 10 명에 대하여 $18 \mathrm{G}, 10 \mathrm{~mm}$ 바늘 전극을 이용해 EUS-RFA를 시행하였다. 20-30 W의 에너지를 사용하였으며, 에너지 전달 시간은 285초(100-560초)였다. 치료 반응 평가를 위해 시술 30 일 후 시행한 복부 CT에서 10 명의 환자 모두에서 종양 내부에 저음영의 괴사 영역이 관찰되었다.
시술 후 합병증은 무증상의 소량의 복수(2명)와 췌장 주위 체액 저류(2명) 등이 있었으며, 시술과 관련된 심각한 합병증은 없었다. 위의 동물실험 및 인체에 대한 치료 결과들을 종합하였을 때 EUS-RFA는 절제 불가능한 췌장암 환자에게 기술적으로 안전하게 적용 가능하며, 기존의 전신 항암화학치료에 보조적으로 적용하거나 항암치료의 전신 부작용의 위험이 큰 환자에서 대안적인 치료 방법으로 고려될 수 있을 것이다.

\section{2) IRE}

IRE는 종양 내부 및 주변에 삽입된 바늘 전극 사이에 발생하는 고전압 전기 펄스를 이용하여 국소적으로 종양을 절제하는 비열성 절제 기술이다. 전기 펄스는 종양 세포막에 나노 포어(nanopores)를 생성함으로써 비가역적 손상을 주어 세포 자멸(apoptosis)을 유도한다. ${ }^{37}$ Martin 등 ${ }^{38}$ 은 수술적 절제가 불가능한 췌장암 환자들을 대상으로 표준 요법(항암화학

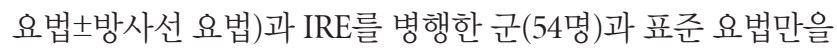
시행 받은 군(85명)의 예후를 비교한 연구 결과를 발표하였는데, IRE를 병행한 환자군에서 local progression-free survival (12 vs. 6 months, $p=0.01$ )과 distant progression-free survival ( 15 vs. 9 months, $p=0.02$ ), overall survival ( 20 vs. 13 months, $p=0.03$ )의 유의한 개선을 보였다. 이 외에도 최근 소개되었던 다른 연구 결과들에서도 IRE가 절제 불가능한 췌장암의 국소 치료에 안전하고 효과적인 치료 방법임을 제시하고 있지만 연구에 등록된 환자의 수가 적어 그 효과와 안전성을 입증하기에는 부족한 점이 있다. ${ }^{39,40}$

췌장 주위의 주요 혈관이나 담관 및 신경 등에 열 손상을 유발할 수 있는 RFA와는 달리 비열성 절제술인 IRE는 이러한 열 손상을 최소화할 수 있다는 연구 결과들이 보고되었다. ${ }^{41-43}$ 그러나 고강도 전류를 사용한 일부 조건에서 비가역적 전기 천공술 역시 열 치료에 의해 생성된 것과 유사한 응고 괴사를 일으킬 수 있으며, 이러한 세포 손상은 고강도 전류에 의한 부분적 열 손상에 의한 것이라는 보고도 있어, ${ }^{44}$ 비가역적 전기전공술의 안전성에 대한 추가 연구 및 이 기법을 안전하게 적용할 수 있는 도구들의 개발이 중요하다 할 수 있겠다.

기존의 IRE는 주로 CT-유도하 경피적 방법, 개복 또는 복강경 수술 중 종양에 전극을 삽입하는 방식으로 시행되었다. ${ }^{45}$ 그러나 EUS 기술 및 장비의 발달로 IRE도 EUS 유도하에 좀 더 안전하고 정확하게 시행될 수 있을 것이라는 기대를 하게 되었으며, 최근 Lee 등 ${ }^{46}$ 은 EUS에 사용할 수 있도록 개발된 
새로운 전극을 이용한 동물실험을 통해 EUS 유도하 IRE의 효용성과 재현성에 대한 연구 결과를 발표하였다. 추후 EUS에 사용될 수 있는 표준화된 바늘 전극의 개발과 안전하고 효과적인 적절한 전압의 설정 및 임상 적용을 입증할 수 있는 추가적인 연구가 수반되어야 할 것으로 사료된다.

\section{3. 방사선 치료}

\section{1) EUS 유도하 방사선 표식자 삽입술}

정위체부방사선치료(stereotactic body radiation therapy, $\mathrm{SBRT}$ )는 사이버 나이프 등을 이용해 종양 부위에 집중적으로 고선량의 방사선을 조사하는 방법으로, 통상적인 방사선 치료와 비교하여 치료 기간이 짧고, 여러 연구들을 통해 수술이 불가능한 췌장암에서도 효과적임이 입증되었다. ${ }^{47-49} \mathrm{Jung}$ 등 ${ }^{50}$ 은 2011년부터 2016년까지 단일 기관에서 치료받은 국소 진행성 췌장암 환자 95 명의 치료 성적에 대하여 후향적 분석을 시행하였으며, 전신 항암화학 치료와 SBRT를 동시에 시행 받은 환자군에서 freedom from local disease progression과 overall survival이 더 좋았으며, 치료 독성도 적게 나타났던 것으로 보고하였다. 췌장암에 SBRT를 적용하는 데 있어 중요한 문제 중 하나는 호흡에 따른 움직임을 극복해야 한다는 점이다. 두개 내 종양과는 달리 췌장은 두개골과 같은 고정된 공간 내에 존재하지 않기 때문에 호흡 주기 동안 2-3 cm 정도 움직일 것으로 추정된다. ${ }^{51}$ 췌장암의 경계 부위에 삽입된 fiducial marker는 종양 내에서 고정된 기준점으로 작용하여 정위적 방사선 치료 시 표적의 움직임을 극복하는 데 도움을 준다. ${ }^{52}$ 전통적으로 fiducial marker는 CT 또는 초음파 유도하에 경피적으로 삽입되었다. ${ }^{53}$ 그러나 후복막에 위치한 췌장의 특성 상 경피적 fiducial marker 삽입술은 혈관 손상의 위험이 높고, 정확도가 떨어지는 단점이 있다. ${ }^{54}$ 이에 Park 등 ${ }^{55}$ 은 EUS를 이용한 fiducial marker의 삽입술은 실시간 도플러 영상을 사용하기 때문에 출혈의 위험성이 적을 것으로 예상하고, 57 명의 국소 진행성 췌장암 환자들에게 EUS 유도하 fiducial marker 삽입술을 시행하였다. 이 연구에서는 한 명의 환자에서만 경미한 출혈을 보였다고 보고하였다.

경피적 접근 방법의 다른 위험성으로 드물지만 종양의 복막 파종이 있을 수 있다. CT 또는 초음파 유도하 세침흡입술(fine needle aspiration) 시 종양의 복막 파종이 $0.005-0.009 \%$ 정도에서 발생하는 것으로 생각되고 있다. ${ }^{53}$ 그러나 EUS를 통한 접근 방법은 천공 경로가 경피적 방법에 비해 매우 짧기 때문에
종양의 복막 파종 위험성이 적을 것이고 생각되고 있다. $53,55,56$

이처럼 EUS 유도하 fiducial marker 삽입술은 국소 진행성 췌장암 환자의 SBRT를 준비하기 위한 필수적인 절차로 자리 잡아가고 있으며, 다른 방법들과 비교하여 기술적으로 안전하고 정확한 접근법이라할수 있겠다.

\section{2) EUS 유도하 근접 치료}

근접 치료는 방사성 선원(radioactive source)을 종양 조직 또는 종양 주변에 삽입하여 종양을 치료하는 방법이다. 근접 치료에 사용되는 방사성 선원은 iodine-125, iridium-192, palladium-103 등이 있으며, iodine-125의 반감기가 가장 길기 때문에 종양의 성장 속도가 빠른 췌장암에 유용할 것으로 사료된다. ${ }^{57}$ Sun 등 ${ }^{58}$ 은 동물실험을 통해 EUS를 이용하여 방사성 선원을 췌장에 안전하게 삽입할 수 있음을 보여주었다. 이후 절제 불가능한 췌장암 환자 15 명을 대상으로 한 EUS 유도하 brachytherapy의 pilot study에서 12 명의 환자가 안정 병변 상태를 유지하거나 부분 치료 반응을 보였고, $30 \%$ 의 환자에서 통증 감소와 같은 임상 증상의 호전을 보였다. 중앙 생존기간은 10.6 개월이었다. ${ }^{59}$ 또한, 최근 Bhutani 등 ${ }^{60}$ 은 국소 진행 췌장암 환자에서 표준 항암화학요법과 함께 새로운 방사성 선원인 phosphorus-32 microparticles (P-32, OncoSil)를 이용한 근접 치료를 병용하여 종양 용적이 $58 \%$ 감소하였다고 보고하였다. 향후 새로운 방사성 선원의 개발과 함께, 치료 성적에 대한 더 많은 자료가 필요할 것으로 생각된다.

\section{4. 약물방출 스텐트}

췌장암에 의한 악성 담도 폐쇄에 대해서는 역행성 내시경적 담도 배액술이 필수적인 치료이다. ${ }^{61,62}$ 자가 팽창형 금속 스텐트(self-expandable metal stents, SEMS)가 플라스틱 스텐트보다 수명이 길고 개통성이 우수하다고 보고되고 있으나, ${ }^{63,64}$ 금속 스텐트는 스텐트의 그물망을 통해 자라오는 내성장(ingrowth) 및 스텐트의 위, 아래를 통해 스텐트 내로 침범하는 과증식(overgrowth) 등에 의해 스텐트 폐쇄가 일어나기 쉬운 단점이 있다. ${ }^{65}$ 이에 Song 등 ${ }^{66}$ 은 수술 불가능한 악성 담도 폐쇄 환자 52명을 대상으로 paclitaxel-eluting covered metal stent (PECMS)와 control covered metal stent (CCMS)를 각각 26 명에게 삽입한 후 관찰하는 전향적 연구를 시행하였으나, 두 군에서 스텐트 수명과 생존율의 차이를 보이지 않았다. 이후 Jang 등 ${ }^{67}$ 이 1세대 paclitaxel-eluting stent를 
개량한 2세대 drug-eluting metal stent (MSCPM-II)를 이용하여 절제 불가능한 악성 담도 폐쇄 환자 106명을 대상으로 전향적 연구를 시행하였으나, 역시 스텐트 수명과 생존율에서의 차이를 보이지 않았다. 추후 스텐트 내에서 약물의 지속적인 방출을 장기간 유지하여 스텐트 수명을 늘리고 나아가 환자의 수명까지 연장시킬 수 있는 새로운 약물-방출 스텐트의 개발을 위한 지속적인 연구가 필요하다.

\section{결 론}

최근 EUS 장비와 이를 시행하는 임상의들의 숙련도가 급격히 향상되면서 기존에 시행되던 췌장암의 치료와 병행하여 내시경적 국소 치료의 종류 및 적용 범위가 점차 확대되고 있다. 특히 국소진행성 췌장암에 대한 내시경적 국소 치료를 통해 종양의 크기가 감소하여 수술이 가능해질 수도 있다. 궁극적으로는 진행성 췌장암 환자의 생존율을 향상시킴과 동시에 통증 및 담도 폐쇄 등의 합병증을 조절하여 환자의 삶의 질을 높이는 데 기여할 수 있을 것으로 기대된다. 이러한 목표에 도달하기 위하여 내시경 장비 및 다양한 부속 기구들에 대한 지속적인 개발과 다학제적인 임상 연구가 적극적으로 진행되어야 할 것으로 사료된다.

\section{요 약}

췌장암은 예후가 불량하며, 수술적 절제를 통해서만 완치를 기대할 수 있으나 $20 \%$ 내외의 환자만이 근치적 절제가 가능한 병기에서 진단이 된다. 또한 전신 항암화학치료에 대한 반응도 좋지 않아 항암화학 요법의 개선에도 불구하고 절제 불가능한 췌장암의 예후는 특히 불량하다. 국소진행성 췌장암의 경우 조기의 적극적인 치료로 종양의 용적을 감소시켜 병기를 낮출 수 있다면 수술적 치료가 가능해질 가능성이 있기 때문에 전신 항암화학요법과 병행하는 내시경적 국소 치료의 중요성이 더욱 높다고 할 수 있다. 국소 치료의 종류로는 항암제나 바이러스 벡터를 종양에 주입하는 EUS-FNI와 RFA, IRE 등의 국소 종양 제거술(local ablative therapy), 정위적 방사선 치료를 위한 표식자 삽입(fiducial marker insertion), 악성 담도 폐쇄 시 삽입한 스텐트 기능 유지를 위한 약물-배출 스텐트 삽입 등이 있다.
국문 색인: 국소진행성 췌장암, 췌장암, 내시경적 국소 치료

\section{Conflicts of Interest}

The authors have no conflicts to disclose.

\section{REFERENCES}

1. National Cancer Center. Cancer Statistics for 2016 [Internet]. Goyang: National Cancer Center; 2019. Available from: http://ncc. re.kr/cancerStatsView.ncc?bbsnum=459\&searchKey=total\&search Value $=\&$ pageNum=1, 2019.

2. Ducreux M, Cuhna AS, Caramella C, et al. Cancer of the pancreas: ESMO Clinical Practice Guidelines for diagnosis, treatment and follow-up. Ann Oncol 2015;26(Suppl 5):v56-v68.

3. Tucker ON, Rela M. Controversies in the management of borderline resectable proximal pancreatic adenocarcinoma with vascular involvement. HPB Surg 2008;2008:839503.

4. Gurusamy KS, Kumar S, Davidson BR, Fusai G. Resection versus other treatments for locally advanced pancreatic cancer. Cochrane Database Syst Rev 2014:CD010244.

5. Conroy $T$, Desseigne $F$, Ychou M, et al. FOLFIRINOX versus gemcitabine for metastatic pancreatic cancer. N Engl J Med 2011:364:1817-1825.

6. Von Hoff DD, Ervin T, Arena FP, et al. Increased survival in pancreatic cancer with nab-paclitaxel plus gemcitabine. N Engl J Med 2013;369:1691-1703.

7. Tamm EP, Balachandran A, Bhosale PR, et al. Imaging of pancreatic adenocarcinoma: update on staging/resectability. Radiol Clin North Am 2012;50:407-428.

8. Cardenes HR, Moore AM, Johnson CS, et al. A phase II study of gemcitabine in combination with radiation therapy in patients with localized, unresectable, pancreatic cancer: a Hoosier Oncology Group study. Am J Clin Oncol 2011;34:460-465.

9. Hirooka Y, Itoh A, Kawashima H, et al. A combination therapy of gemcitabine with immunotherapy for patients with inoperable locally advanced pancreatic cancer. Pancreas 2009;38:e69-e74.

10. Heinemann $V$, Haas $M$, Boeck S. Neoadjuvant treatment of borderline resectable and non-resectable pancreatic cancer. Ann Oncol 2013;24:2484-2492. 
11. Song TJ, Seo DW, Lakhtakia S, et al. Initial experience of EUSguided radiofrequency ablation of unresectable pancreatic cancer. Gastrointest Endosc 2016;83:440-443.

12. Pandya GJ, Shelat VG. Radiofrequency ablation of pancreatic ductal adenocarcinoma: the past, the present and the future. World J Gastrointest Oncol 2015;7:6-11.

13. Feig C, Gopinathan A, Neesse A, Chan DS, Cook N, Tuveson DA. The pancreas cancer microenvironment. Clin Cancer Res 2012;18:4266-4276.

14. Levy MJ, Alberts SR, Chari ST, et al. 716 EUS guided intra-tumoral gemcitabine therapy for locally advanced and metastatic pancreatic cancer. Gastrointest Endosc 2011;73:AB144-AB145.

15. Matthes K, Mino-Kenudson M, Sahani DV, et al. EUS-guided injection of paclitaxel (OncoGel) provides therapeutic drug concentrations in the porcine pancreas (with video). Gastrointest Endosc 2007;65:448-453.

16. Vacchelli E, Eggermont A, Sautes-Fridman C, et al. Trial watch: oncolytic viruses for cancer therapy. Oncoimmunology 2013;2:e24612.

17. Hecht JR, Bedford R, Abbruzzese JL, et al. A phase I/II trial of intratumoral endoscopic ultrasound injection of ONYX-015 with intravenous gemcitabine in unresectable pancreatic carcinoma. Clin Cancer Res 2003;9:555-561.

18. Fu X, Tao L, Li M, Fisher WE, Zhang X. Effective treatment of pancreatic cancer xenografts with a conditionally replicating virus derived from type 2 herpes simplex virus. Clin Cancer Res 2006;12:3152-3157.

19. Nakao A, Kasuya H, Sahin TT, et al. A phase I dose-escalation clinical trial of intraoperative direct intratumoral injection of HF10 oncolytic virus in non-resectable patients with advanced pancreatic cancer. Cancer Gene Ther 2011;18:167-175.

20. Melcher A, Parato K, Rooney CM, Bell JC. Thunder and lightning: immunotherapy and oncolytic viruses collide. Mol Ther 2011;19:1008-1016.

21. Campadelli-Fiume G, De Giovanni C, Gatta V, Nanni P, Lollini PL, Menotti L. Rethinking herpes simplex virus: the way to oncolytic agents. Rev Med Virol 2011;21:213-226.

22. Wennier ST, Liu J, Li SD, Rahman MM, Mona M, McFadden G. Myxoma virus sensitizes cancer cells to gemcitabine and is an effective oncolytic virotherapeutic in models of disseminated pancreatic cancer. Mol Ther 2012;20:759-768.

23. Angelova AL, Aprahamian M, Grekova SP, et al. Improvement of gemcitabine-based therapy of pancreatic carcinoma by means of oncolytic parvovirus H-1PV. Clin Cancer Res 2009;15:511-519.

24. Galanis E. Therapeutic potential of oncolytic measles virus: promises and challenges. Clin Pharmacol Ther 2010;88:620-625.

25. Chang KJ, Nguyen PT, Thompson JA, et al. Phase I clinical trial of allogeneic mixed lymphocyte culture (cytoimplant) delivered by endoscopic ultrasound-guided fine-needle injection in patients with advanced pancreatic carcinoma. Cancer 2000;88:1325-1335.

26. Nonogaki $K$, Hirooka Y, Itoh A, et al. Combined treatment with immunotherapy and chemotherapy using endoscopic ultrasonography: a phase 1 trial as first-line treatment in patients with locally advanced pancreatic carcinoma. Gastrointest Endosc 2007;65:Ab207-Ab207.

27. Hecht JR, Farrell JJ, Senzer N, et al. EUS or percutaneously guided intratumoral TNFerade biologic with 5-fluorouracil and radiotherapy for first-line treatment of locally advanced pancreatic cancer: a phase I/II study. Gastrointest Endosc 2012;75:332-338.

28. Mallery S, Goldberg SN, Brugge WR. EUS-guided radiofrequency ablation in the pancreas: preliminary results in a porcine model. Gastrointest Endosc 1998;47:Ab34.

29. Dromi SA, Walsh MP, Herby $S$, et al. Radiofrequency ablation induces antigen-presenting cell infiltration and amplification of weak tumor-induced immunity. Radiology 2009;251:58-66.

30. Teng $L S$, Jin $K T$, Han N, Cao J. Radiofrequency ablation, heat shock protein 70 and potential anti-tumor immunity in hepatic and pancreatic cancers: a minireview. Hepatobiliary Pancreat Dis Int 2010;9:361-365.

31. Rossi S, Viera FT, Ghittoni G, et al. Radiofrequency ablation of pancreatic neuroendocrine tumors: a pilot study of feasibility, efficacy, and safety. Pancreas 2014;43:938-945.

32. Wu Y, Tang Z, Fang H, et al. High operative risk of cool-tip radiofrequency ablation for unresectable pancreatic head cancer. J Surg Oncol 2006;94:392-395.

33. Arcidiacono PG, Carrara S, Reni M, et al. Feasibility and safety of EUS-guided cryothermal ablation in patients with locally advanced pancreatic cancer. Gastrointest Endosc 2012;76:1142-1151.

34. Goldberg SN, Mallery S, Gazelle GS, Brugge WR. EUS-guided radiofrequency ablation in the pancreas: results in a porcine model. 
Gastrointest Endosc 1999:50:392-401.

35. Kim HJ, Seo DW, Hassanuddin A, et al. EUS-guided radiofrequency ablation of the porcine pancreas. Gastrointest Endosc 2012;76:1039-1043.

36. Scopelliti F, Pea A, Conigliaro R, et al. Technique, safety, and feasibility of EUS-guided radiofrequency ablation in unresectable pancreatic cancer. Surg Endosc 2018;32:4022-4028.

37. Rubinsky B, Onik G, Mikus P. Irreversible electroporation: a new ablation modality--clinical implications. Technol Cancer Res Treat 2007;6:37-48.

38. Martin RC, 2nd, McFarland K, Ellis S, Velanovich V. Irreversible electroporation in locally advanced pancreatic cancer: potential improved overall survival. Ann Surg Oncol 2013;20(Suppl 3):S443S449.

39. Narayanan G, Hosein PJ, Arora G, et al. Percutaneous irreversible electroporation for downstaging and control of unresectable pancreatic adenocarcinoma. J Vasc Interv Radiol 2012;23:1613-1621.

40. Mansson C, Bergenfeldt M, Brahmstaedt R, Karlson BM, Nygren P, Nilsson A. Safety and preliminary efficacy of ultrasound-guided percutaneous irreversible electroporation for treatment of localized pancreatic cancer. Anticancer Res 2014;34:289-293.

41. Maor E, Ivorra A, Leor J, Rubinsky B. Irreversible electroporation attenuates neointimal formation after angioplasty. IEEE Trans Biomed Eng 2008;55:2268-2274.

42. Maor E, Ivorra A, Rubinsky B. Intravascular irreversible electroporation: theoretical and experimental feasibility study. 30th Annual International Conference of the IEEE Engineering in Medicine and Biology Society. pp. 2051-2054, IEEE, 2008.

43. Schoellnast $H$, Monette $S$, Ezell $P C$, et al. Acute and subacute effects of irreversible electroporation on nerves: experimental study in a pig model. Radiology 2011;260:421-427.

44. Faroja M, Ahmed M, Appelbaum L, et al. Irreversible electroporation ablation: is all the damage nonthermal? Radiology 2013;266:462-470.

45. Holzgang M, Eigl B, Erdem S, Gloor B, Worni M. Irreversible electroporation in pancreatic cancer. In: Rodrigo $\mathrm{M}$, eds. Advances in pancreatic cancer. pp 97-114, Hamburg, Books on Demand, 2018.

46. Lee JM, Choi HS, Chun HJ, et al. EUS-guided irreversible electroporation using endoscopic needle-electrode in porcine pancreas. Surg Endosc 2019;33:658-662.
47. Schellenberg D, Goodman KA, Lee F, et al. Gemcitabine chemotherapy and single-fraction stereotactic body radiotherapy for locally advanced pancreatic cancer. Int J Radiat Oncol Biol Phys 2008;72:678-686.

48. Chang DT, Schellenberg D, Shen J, et al. Stereotactic radiotherapy for unresectable adenocarcinoma of the pancreas. Cancer 2009;115:665-672.

49. Hoyer M, Roed H, Sengelov L, et al. Phase-Il study on stereotactic radiotherapy of locally advanced pancreatic carcinoma. Radiother Oncol 2005;76:48-53.

50. Jung J, Yoon SM, Park JH, et al. Stereotactic body radiation therapy for locally advanced pancreatic cancer. PLoS One 2019;14:e0214970.

51. Bussels B, Goethals L, Feron $M$, et al. Respiration-induced movement of the upper abdominal organs: a pitfall for the threedimensional conformal radiation treatment of pancreatic cancer. Radiother Oncol 2003;68:69-74.

52. Chang BK, Timmerman RD. Stereotactic body radiation therapy: a comprehensive review. Am J Clin Oncol 2007;30:637-644.

53. Choi JH, Seo DW, Park DH, Lee SK, Kim MH. Fiducial placement for stereotactic body radiation therapy under only endoscopic ultrasonography guidance in pancreatic and hepatic malignancy: practical feasibility and safety. Gut Liver 2014;8:88-93.

54. Kothary N, Heit JJ, Louie JD, et al. Safety and efficacy of percutaneous fiducial marker implantation for image-guided radiation therapy. J Vasc Interv Radiol 2009;20:235-239.

55. Park WG, Yan BM, Schellenberg D, et al. EUS-guided gold fiducial insertion for image-guided radiation therapy of pancreatic cancer: 50 successful cases without fluoroscopy. Gastrointest Endosc 2010;71:513-518.

56. Micames $C$, Jowell PS, White $R$, et al. Lower frequency of peritoneal carcinomatosis in patients with pancreatic cancer diagnosed by EUS-guided FNA vs. percutaneous FNA. Gastrointest Endosc 2003;58:690-695.

57. Jin Z, Chang KJ. Endoscopic ultrasound-guided fiducial markers and brachytherapy. Gastrointest Endosc Clin N Am 2012;22:325331.

58. Sun S, Qingjie L, Qiyong G, Mengchun W, Bo Q, Hong X. EUSguided interstitial brachytherapy of the pancreas: a feasibility study. Gastrointest Endosc 2005;62:775-779. 
59. Sun S, Xu H, Xin J, Liu J, Guo Q, Li S. Endoscopic ultrasoundguided interstitial brachytherapy of unresectable pancreatic cancer: results of a pilot trial. Endoscopy 2006;38:399-403.

60. Bhutani MS, Cazacu IM, Luzuriaga Chavez AA, et al. Novel EUS-guided brachytherapy treatment of pancreatic cancer with phosphorus-32 microparticles: first United States experience. VideoGIE 2019;4:223-225.

61. Andersen JR, Sorensen SM, Kruse A, Rokkjaer M, Matzen P. Randomised trial of endoscopic endoprosthesis versus operative bypass in malignant obstructive jaundice. Gut 1989;30:1132-1135.

62. Smith AC, Dowsett JF, Russell RC, Hatfield AR, Cotton PB. Randomised trial of endoscopic stenting versus surgical bypass in malignant low bileduct obstruction. Lancet 1994;344:1655-1660.

63. Wagner HJ, Knyrim K, Vakil N, Klose KJ. Plastic endoprostheses versus metal stents in the palliative treatment of malignant hilar biliary obstruction. A prospective and randomized trial. Endoscopy
1993;25:213-218.

64. O'Brien S, Hatfield AR, Craig PI, Williams SP. A three year follow up of self expanding metal stents in the endoscopic palliation of longterm survivors with malignant biliary obstruction. Gut 1995;36:618-621.

65. Hausegger KA, Kleinert R, Lammer J, Klein GE, Fluckiger F. Malignant biliary obstruction: histologic findings after treatment with self-expandable stents. Radiology 1992;185:461-464.

66. Song TJ, Lee SS, Yun SC, et al. Paclitaxel-eluting covered metal stents versus covered metal stents for distal malignant biliary obstruction: a prospective comparative pilot study. Gastrointest Endosc 2011;73:727-733.

67. Jang SI, Lee KT, Choi JS, et al. Efficacy of a paclitaxel-eluting biliary metal stent with sodium caprate in malignant biliary obstruction: a prospective randomized comparative study. Endoscopy 2019;51:843-851. 